THE INTERNATIONAL

REVIEW OF RESEARCH IN

OPEN AND DISTANCE LEARNING

\title{
Applying the Community of Inquiry Framework to an Online Professional Practice Doctoral Program
}
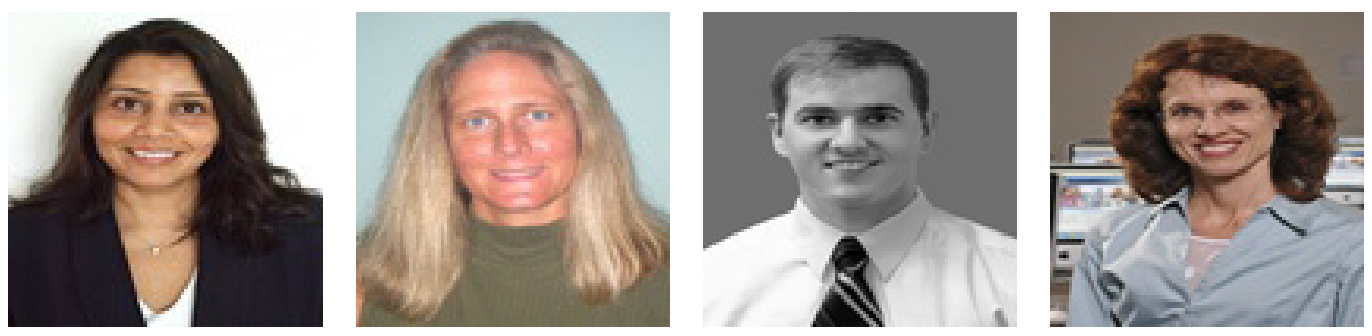

Swapna Kumar, Kara Dawson, Erik W. Black, Catherine Cavanaugh, and Christopher D. Sessums University of Florida, USA

\section{Abstract}

The community of inquiry (CoI) framework has commonly been used to study teaching and learning in online courses (Garrison, Anderson, \& Archer 2000). This paper describes the implementation of the CoI framework in a cohort-based online EdD program, where teaching presence and cognitive presence were easier to foster than social presence. Based on the results of an initial evaluation, suggestions are made to expand the components of the CoI framework when using it at a program level. Lessons learned from the implementation are also shared to assist others wishing to apply the CoI framework to online graduate programs.

Keywords: Distance education; professional practice doctorate; higher education, community of inquiry (CoI) framework

\section{Introduction}

The College of Education at the University of Florida was engaged with colleagues participating in the Carnegie Project on the Education Doctorate (CPED), a national effort in the US aimed at strengthening the education doctorate (EdD), from 2007-2010. The EdD, sometimes referred to as a professional practice doctorate, is designed to prepare stewards of practice (Perry \& Imig, 2008). That is, the degree guides students to apply researchbased knowledge and to generate context-based knowledge to improve and advance practice (Shulman, Golde, Conklin, Bueschel, \& Garabedian, 2006).

As a result of our institution's participation in CPED, we designed an EdD in curriculum and instruction with a focus on educational technology. The professional practice program combines the professional practice vision (Shulman et al., 2006) with a cohort-based format that includes online coursework and interactions with a one-week session on campus 
each year. Our program design was guided by the community of inquiry (CoI) framework (Garrison et al., 2000), a structure highlighting the importance of teaching presence, social presence, and cognitive presence in online teaching and learning. This article describes the implementation and evaluation of the first year of the cohort-based EdD program in the context of this model. The description of implementation and research, and the ways in which this model applies to online teaching and learning, could be useful to other institutions engaged in online graduate programs.

\section{Applying CoI to an Online EdD in Educational Technology}

The community of inquiry (CoI) proposed by Garrison et al. (2000) is a theoretical framework that has been used to study online teaching and learning during the past decade. The EdD program was conceptualized as a community of inquiry where students advance through a structured program as a cohort. They have common goals, purposefully interact with and support one another, and are intensively supported by faculty members in order to complete the program. In this section we review the three main components of the CoI framework (i.e., teaching presence, social presence, and cognitive presence) and use it as a lens to examine the program.

\section{Teaching Presence}

Teaching presence, defined as "the design, facilitation, and direction of cognitive and social processes for the purpose of realizing personally meaningful and educationally worthwhile learning outcomes," (Anderson, Rourke, Garrison, \& Archer, 2001, p. 5) is crucial for student learning, for student satisfaction, and for the creation of a community of inquiry according to several researchers (Arbaugh \& Hwang, 2006; Blignaut \& Trollip, 2003; Garrison \& Cleveland-Innes, 2005; Kanuka, Rourke, \& Laflamme, 2007; Lim \& Barnes, 2002; Meyer, 2003; Murphy, 2004; Shea, Fredericksen, Pickett, \& Pelz, 2003; Shea, Pickett, \& Pelz, 2004; Swan, 2003; Wu \& Hiltz, 2004). In the absence of face-to-face interactions, an instructor's ability to design, plan, structure, and organize an online course becomes extremely important (Swan, 2003; 2004). In addition to instructional design and organization, Anderson et al. (2001) identified two other components of teaching presence, namely building understanding and direct instruction. These include the facilitation of student participation and the management of discourse to increase learner knowledge and critical thinking; the provision of effective, explanatory, and immediate feedback; and the leadership of the instructor, who imparts knowledge as a subject matter expert (SME).

\section{Social Presence}

Some researchers have found student trust, reliance, and sense of belonging (also called sense of community) are high indicators of perceived learning and satisfaction in online courses (Benbunan-Fich, Hiltz, \& Harasim, 2005; Rovai, 2002). Sense of community, or social presence, is considered a prerequisite for achieving a deeper level of intellectual discourse. In the community of inquiry, social presence in online environments has been defined as the way that learners portray themselves as "real people" in their online interactions in the absence of face-to-face communication (Garrison et al., 2000, p. 89). Many researchers have studied social presence, often by examining asynchronous online discus- 
sions in online courses, and have found that it influences learning outcomes and students' cognitive presence (Arbaugh, 2005; Celani \& Collins, 2005; Gunawardena \& Zittle, 1997; Hughes, Ventura, \& Dando, 2007; Molinari, 2004; Richardson \& Swan, 2003; Swan \& Shih, 2005). In her study of social presence online, Swan (2003) reported that there was an increase in group cohesion and purposeful communication in online discussions after the class established social relationships.

\section{Cognitive Presence}

The extent to which students can construct and apply meaning using sustained reflection and discourse has been termed cognitive presence by Garrison, Anderson, and Archer (2001). Cognitive presence is developed in four stages: the identification of a problem, the exploration of the problem individually and collectively through discourse, the integration or construction of meaning through exploration, and the resolution or application of meaning to new contexts (Garrison, 2003). Cognitive presence depends greatly on the instructor, the instructional design of online activities, course structure, leadership, and the questions created by the instructor (Arnold \& Ducate, 2006; Celentin, 2007; Garrison et al., 2001; Garrison \& Cleveland-Innes, 2005; Luebeck \& Bice, 2005; Meyer, 2003; 2004). Social presence, or sense of community, has also been found to influence cognitive presence and learner outcomes in an online course (Rovai, 2002).

\section{Program Design}

As described in the CoI, all instructors in the first year of the online EdD program adopted the roles of instructional designer, administrator, subject matter expert, facilitator, and teacher. All the faculty members had prior online teaching experience, instructional design experience, and experience mentoring graduate students. We deliberately structured the program to be more than a sequence of courses that students completed as a cohort. Several other experiences and activities were designed to enculturate students into the educational technology field, to familiarize them with the expectations and rigors of doctoral study, and to expose them to research and professional organizations in the discipline. We intended these elements of the online program to ensure teaching presence and facilitate cognitive

and social presence in the EdD cohort. Table 1 provides a summary of the key features of the program and how they relate to the CoI framework. 
Table 1

Key Program Features Mapped to CoI Components

\begin{tabular}{lccc}
\hline & $\begin{array}{c}\text { Teaching pres- } \\
\text { ence }\end{array}$ & $\begin{array}{c}\text { Social pres- } \\
\text { ence }\end{array}$ & $\begin{array}{c}\text { Cognitive pres- } \\
\text { ence }\end{array}$ \\
\hline Online courses & $\mathrm{X}$ & $\mathrm{X}$ & $\mathrm{X}$ \\
\hline Campus experiences & $\mathrm{X}$ & $\mathrm{X}$ & $\mathrm{X}$ \\
\hline Inquiry groups & & $\mathrm{X}$ & $\mathrm{X}$ \\
\hline Synchronous sessions & $\mathrm{X}$ & $\mathrm{X}$ & $\mathrm{X}$ \\
\hline Asynchronous experiences & $\mathrm{X}$ & $\mathrm{X}$ & $\mathrm{X}$ \\
\hline
\end{tabular}

\section{Online courses.}

We designed online courses in the program to include multiple forms of synchronous and asynchronous interaction (Moore \& Anderson, 2003), frequent opportunities for reflection (Ainsworth \& Loizou, 2003), support for a variety of learning styles via distributed practice with concepts and skills (Cepeda, Pashler, Vul, Wixted, \& Rohrer, 2006), multimedia resources (Moreno \& Valdez, 2005), and multiple assessment formats (McTighe \& O’Connor, 2005). We used Moodle, an open source learning management system (LMS), to host all the online courses. Students completed four required online courses as a cohort in the fall and spring semesters of the first year. The purpose of these courses was to orient students to research and doctoral study in educational technology and to foster critical thinking, or cognitive presence. All projects were specific to students' professional context and allowed flexibility within certain parameters. Faculty who taught EdD courses discussed the design and content of the courses to ensure consistency across the program.

\section{Summer campus experience.}

At the end of their first year, students took a summer seminar that consisted of online activities to prepare for the one-week campus-based experience and follow-up online assignments. Program faculty collaboratively led the campus experience, which was intended to help students get acquainted with the university through interactions with one another, faculty both in and outside the program, administrators, and librarians. The first on-campus seminar served to cement the social presence that had developed online, model the teaching presence in a synchronous setting, and support cognitive presence by reinforcing the memory of content learned in the first year.

\section{Inquiry groups.}

In their first semester of the program, we grouped students according to their area of specialization to work together and support one another online. We intended the inquiry groups of five or six students with common contexts and interests to support social pres- 
ence and cognitive presence within the larger online community of practice.

\section{Synchronous sessions (Elluminate).}

There were monthly real-time conferencing sessions using Elluminate software throughout the first year of the program to maintain communication and continuity outside of courses. The synchronous session topics were faculty- or student-driven and ranged from program questions or student concerns to information sharing about conferences and professional events. Faculty encouraged and modeled a critical approach to educational technology research and events during the sessions that supported all three areas of the CoI framework.

\section{Asynchronous experiences (Google group).}

In order to encourage students to communicate with one another outside of coursework, we integrated several asynchronous opportunities into the program design. We formed a Google group to facilitate social and cognitive presence outside of the cohort's coursework. It served as a repository for resources, a forum for program discussions, and a virtual space where the cohort could interact outside of their courses. Faculty members were "present" and active in the group.

\section{Evaluation Methodology}

Since the program was designed using the CoI framework, we reviewed instruments used to measure teaching presence, social presence, and cognitive presence (Arbaugh et al., 2008; Arbaugh \& Benbunan-Fich, 2003; Garrison et al., 2001; Rourke, Anderson, Garrison, \& Archer, 2001; Shea et al., 2003). However, all the instruments in the literature were for online courses, with some specifically for the analysis of asynchronous interactions in online courses. They were not representative of teaching and learning in an online program. Therefore, we could not use the existing instruments to measure these constructs in this program, and we were unable to find one single course that was representative of the entire program. In the absence of previous program-level research related to the CoI framework, we created a survey to study student perceptions of program implementation and components that corresponded to teaching presence, social presence, and cognitive presence as they had been implemented in the EdD program. The survey consisted of three sections: Faculty Instruction and Feedback; Support, Learning Environments, and CommunityBuilding; and Application of Learning, respectively.

\section{Faculty Instruction and Feedback}

This section included items about student satisfaction with the ways that faculty structured learning and provided feedback. We adapted two items from the teaching presence scale for the program context (Arbaugh \& Hwang, 2006). For example, item P2, "The instructor clearly communicated important course goals" (Arbaugh \& Hwang, 2006, p. 14) was reworded as "The goals and expectations for Year 1 were clear to me" because no one instructor communicated the program goals for the EdD program. Likewise, item $\mathrm{P}_{5}$ was originally 
"The instructor helped me take advantage of the online environment to assist my learning" (Arbaugh \& Hwang, 2006, p. 14), and we reworded it to "The faculty helped me take advantage of the online environment to assist my learning." The reliability (Cronbach's alpha) for this section of the survey was 0.90 (Table 2).

\section{Support, Learning Environments, and Community-Building}

The communication medium used in an online course can influence student satisfaction and perceptions of social presence (So \& Brush, 2007) and is foundational to interactions and the development of social presence. The section on Support, Learning Environments, and Community-Building thus included items on learner satisfaction with technical, library, and administrative support and with the learning environments that were used for communication and interaction in the program. A third set in this section contained questions about students' perceived value of the asynchronous and synchronous interactions for building community (or social presence) in the cohort. The overall reliability (Cronbach's alpha) for this section of the survey was estimated at 0.76 (Table 2).

Table 2

Internal Consistency/Reliability of the Survey

\begin{tabular}{lc}
\hline Section on the survey & $\begin{array}{c}\text { Cronbach's } \\
\text { alpha }\end{array}$ \\
\hline Faculty instruction and feedback & 0.90 \\
Support, learning environments, and community-building & 0.76 \\
Application of learning to practice & 0.96 \\
Total Survey & 0.88 \\
\hline
\end{tabular}

\section{Application of Learning}

Cognitive presence in the research has usually been measured by analyzing online discussions (Garrison, 2003), and researchers have recently included items pertaining to cognitive presence in the CoI instrument developed by Arbaugh et al. (2008). Cognitive presence in the EdD program involved the collective construction of knowledge through discourse among participants in various asynchronous and synchronous learning environments, but the main goal was the sharing and application of that knowledge in their professional practice. We thus focused the questions in this section on application of learning. Based on two cognitive presence items from the CoI instrument for a specific course, "(33.) I have developed solutions to course problems that can be applied in practice," and "(34.) I can apply the knowledge created in this course to my work or other non-class related activities" (Arbaugh et al., 2008, p.135), we created program-specific items. For instance, "I have applied knowledge or skills gained from Year 1 of the EdD program to my practice/work environment," or "I have shared knowledge or skills gained during Year 1 of the EdD program with my peers or colleagues outside the doctoral program" are two examples. Reliability of this section was quite high, with the Cronbach's alpha at 0.96 (Table 2). 
The reliability estimate for the survey, including all three sections, was 0.88 (Table 2). We included open-ended questions about the strengths of the program, the challenges students faced, and a request for suggestions to improve Year 1 for the next cohort.

In October 2009 we sent an email to the 26 students (28\% male, $72 \%$ female) enrolled in the second year of the EdD program, inviting them to complete a survey about their first year experiences. The online survey was hosted by SurveyMonkey, and students completed it anonymously; no identifying data were collected and no IP addresses were tracked. Data collected from 16 students (61\%) were imported into SPSS and analyzed. Open-ended responses were imported into NVivo software and coded.

\section{Findings}

The results from student surveys are organized in Table 3 according to the areas in the survey: Faculty Instruction and Feedback (teaching presence); Support, Learning Environments, and Community-building (social presence); and Application of Student Learning (cognitive presence).

Table 3

Survey Results $(N=16)$

\section{Faculty Instruction and Feedback}

\begin{tabular}{lcc}
\hline $\begin{array}{l}\text { (5 = Strongly Agree; } 1=\text { Strongly Disagree) } \\
\text { Mean }\end{array}$ & SD \\
$\begin{array}{l}\text { The goals and expectations for Year 1 were clear } \\
\text { to me. }\end{array}$ & 3.87 & .806 \\
\hline $\begin{array}{l}\text { My expectations were met during Year } 1 . \\
4.37\end{array}$ & .619 \\
\hline $\begin{array}{l}\text { I learned a lot from the faculty. } \\
\text { I learned a lot from my peers in the EdD cohort. }\end{array}$ & 3.81 & .634 \\
\hline $\begin{array}{l}\text { The faculty helped me take advantage of the } \\
\text { online environment in a way that assisted my }\end{array}$ & 4.44 & .727 \\
learning. & & \\
\hline $\begin{array}{l}\text { I am satisfied with the timeliness of feedback } \\
\text { provided to me during Year } 1 .\end{array}$ & 4.12 & .957 \\
\hline $\begin{array}{l}\text { I am satisfied with the quality of feedback pro- } \\
\text { vided to me during Year } 1 .\end{array}$ & 3.94 & 1.124 \\
\hline $\begin{array}{l}\text { I am satisfied with the support provided to me } \\
\text { by the faculty during Year } 1 .\end{array}$ & 4.56 & .629 \\
\hline
\end{tabular}




\section{Support, Learning Environments, and Community-Building}

Online Support

(5 = Strongly Agree $; 1=$ Strongly Disagree $)$

I am satisfied with the technical support provided to me during Year 1.

I am satisfied with the administrative support provided to me during Year 1 (e.g., registration).

I am satisfied with the instruction and support provided to me for accessing library resources.

Satisfaction with learning environments

( 5 = very satisfied $; 1=$ very dissatisfied $)$

\begin{tabular}{lcc}
\hline Moodle for courses & 4.56 & .727 \\
\hline Google Groups for work outside of courses & 3.00 & .966 \\
\hline Elluminate for synchronous sessions & 4.06 & .854
\end{tabular}

Value of the following for building community in the cohort

$(5=$ very valuable $; 1=$ not valuable $)$

\begin{tabular}{lcc}
\hline Google Groups & 2.56 & 1.094 \\
\hline Discussion forums & 3.81 & 1.047 \\
\hline Elluminate & 3.81 & 1.047 \\
\hline Inquiry groups & 3.53 & 1.060 \\
\hline Summer campus session & 4.88 & .342 \\
\hline
\end{tabular}

\section{Application of Learning}

\begin{tabular}{lcc}
\hline $5=$ Strongly Agree; 1 = Strongly Disagree) & Mean & SD \\
\hline $\begin{array}{l}\text { I have applied knowledge or skills gained from } \\
\text { Year 1 of the EdD program to my practice/work } \\
\text { environment. }\end{array}$ & 4.33 & 1.113 \\
\hline $\begin{array}{l}\text { I have shared knowledge or skills gained during } \\
\text { Year 1 of the EdD program with my peers or col- }\end{array}$ & 4.31 & 1.078 \\
\begin{tabular}{l} 
leagues outside the doctoral program. \\
\hline
\end{tabular} & & \\
\hline
\end{tabular}




\begin{tabular}{|c|c|c|}
\hline $\begin{array}{l}\text { Following my participation in Year } 1 \text { of the EdD } \\
\text { program, I have changed how I approach my } \\
\text { work responsibilities. }\end{array}$ & 3.62 & 1.204 \\
\hline $\begin{array}{l}\text { Following my participation in Year } 1 \text { of the EdD } \\
\text { program, I have a better understanding of my } \\
\text { role as an educational practitioner. }\end{array}$ & 4.06 & 1.063 \\
\hline $\begin{array}{l}\text { Year } 1 \text { of the EdD program has been relevant to } \\
\text { my professional goals. }\end{array}$ & 4.19 & 1.047 \\
\hline $\begin{array}{l}\text { Year } 1 \text { of the EdD program has contributed to } \\
\text { my professional growth. }\end{array}$ & $4 \cdot 31$ & 1.078 \\
\hline
\end{tabular}

\section{Faculty Instruction and Feedback}

In response to questions about their expectations, satisfaction, and sense of faculty support during the EdD program, $94 \%$ of students agreed or strongly agreed that their expectations were met during Year 1 of the program. They were also largely satisfied with the timeliness and quality of feedback provided and learned a great deal from the faculty in the program. When asked in open-ended survey items to comment on the strengths of the program, 67\% of students cited the faculty members and their support as the main strength. One student wrote, "The faculty are all wonderful to work with, have a great depth of knowledge, create learning experiences that connect with authentic, real-world information, and are excellent at keeping contact individually."

\section{Support, Learning Environments, and Community-Building}

Over $75 \%$ of students either agreed or strongly agreed that they were satisfied with the technical and administrative support provided to them in Year 1. In addition to a traditional learning management system for online courses, the program also integrates other asynchronous and synchronous environments, as described earlier. Over $86 \%$ of students were very satisfied or satisfied with the learning management system, Moodle, and with Elluminate, the software used for synchronous sessions. Only 25\% were satisfied with the use of Google Groups for non-course asynchronous experiences. Students reported that there had been inadequate peer interaction outside of the required coursework during the first year of the program. In the optional comments area, several students cited lacking a coordinated time to meet or collaborate online as an obstacle. As one student noted,

I have terrific peers in the cohort, but we are all so busy. A highlight of the summer session was meeting my cohort members, and I really thought the personal interactions would continue, but we haven't really had any reason to partner with each other.

Of the key program features described earlier, the campus-based seminar experience in the summer was rated by students as the most valuable for building community in the cohort. Students suggested that a summer face-to-face meeting at the beginning of the first year of 
the program be included for future cohorts.

\section{Student Learning and Application of Learning to their Practice}

Corresponding to the EdD program goals of facilitating problem-solving and technology integration in students' professional practice, students reported the integration of real-life, authentic projects related to their career objectives as a strength of the program. At least $81 \%$ of students reported that they have applied the knowledge or skills gained from the first year of the EdD program to their practice, have shared new knowledge with peers or colleagues in their professional environment, and have a better understanding of their roles as educators. Eighty-eight percent agreed or strongly agreed that the program has contributed to their professional growth.

\section{Discussion and Significance for Online Programs}

The research reported in this paper was conducted in a cohort-based professional practice doctoral program in educational technology and cannot be generalized to all online programs at all levels of higher education. However, the results point to the usefulness of the CoI framework in conceptualizing and implementing online programs. This section provides suggestions and considerations for the building of a community of inquiry (CoI) in professional practice or doctoral online programs that could be useful to others involved in developing, implementing, and evaluating online programs.

Students cited faculty presence, feedback, and support as a strength of the EdD program. Faculty expertise in online teaching and learning, instructional design, course structure and organization transferred to program design, structure, and organization. A structured course sequence; consistent communication between students and faculty within courses and about program-level issues; the development of respectful relationships based on subject matter expertise, trust, and mentoring; and instruction that promotes students' efforts to apply their knowledge to further their professional goals are all key elements of teaching presence at the program level. Similar to Shea, Hayes, and Vickers' (2010) conclusion that the construct of teaching presence in the CoI framework can include instructor communication and organization in all aspects of an online course, our experiences indicate that additional skills are needed to foster teaching presence in an online program. Faculty not only need excellent online pedagogical skills, organizational skills, and experience with online courses but also have to understand administrative procedures and collaborate with multiple entities in their institution to ensure different types of support (e.g., administrative support, library resources, and research skills) that students at a distance might require in an online program are readily available. Others wishing to develop similar programs must consider these factors and ensure that at least one faculty member in the program has the institutional knowledge necessary to bring together cohesive and multifaceted support.

Evaluation data suggest mixed student satisfaction with social presence in the program. Students reported high satisfaction with asynchronous communication in courses and with synchronous communication during Elluminate sessions and the campus-based experi- 
ence. High student satisfaction in these areas is not surprising, given the faculty members' expertise with online courses and students' familiarity with the learning management system (Moodle) and communication tools used in the program. Further, social presence is easier to facilitate in online course discussions or synchronous sessions where students' participation is mandated. In the EdD program, social presence was more difficult to foster in environments (e.g., the Google group, Inquiry groups) that had been envisioned as unstructured avenues for increased community-building via student interaction and initiative. Students were less satisfied with interactions in these areas. The environments relied heavily on individual student motivation and self-direction (Moore \& Anderson, 2003), areas that are now being highlighted, scaffolded, and directly addressed in activities for both the old and new cohort in the EdD program.

In retrospect, the life cycle of the online community and the importance of faculty leadership during the inception stage (Iriberri \& Leroy, 2009) should have been more carefully considered to foster social presence. In the second cohort, we plan to implement structured and required asynchronous and synchronous interactions in a virtual program space. Faculty members hope to gradually transfer responsibility for interaction to students and will require them to facilitate conversations on topics of interest. We have also introduced a campus-based session to build community and social presence at the beginning of the program for the second cohort. Others wishing to develop similar programs should carefully conceive strategies to facilitate social presence, consider the life cycle of an online community (Iriberri \& Leroy, 2009), and not take student motivation or participation in a given environment for granted.

Cognitive presence in the EdD program took the form of (a) problem definition, exploration, and learning through discourse in multiple asynchronous and synchronous settings; and (b) the regular application of knowledge and skills from the program to students' practice. Traditionally, the former has been studied by conducting a content analysis of online discussions or a survey about learning resulting from interactions at the course level (Garrison, 2003; Arbaugh et al., 2008). However, in our doctoral program, we structured opportunities for students not only to interact with each other in various learning environments but also with peers outside of their program, other professional organizations, and leaders in their professional practice. Such opportunities are crucial for doctoral students, and measures to assess the effectiveness of learning not only through interactions with their cohort but also through interactions during program activities involving non-cohort members have to be developed.

Among other things, students reported applying knowledge and skills learned to their work and sharing the acquired knowledge with others. This parallels the philosophy of professional practice doctoral degrees, which require students to use research and literature in systematic and intentional ways to inform, improve, and solve educational problems in their local contexts (Shulman et al., 2006). The integration of university-based learning and professional practice is expected to lead to the development of important habits of mind that include intentionality, metacognition, critical-mindedness, creativity, clarity of expression in oral and written communication, and a positive stance toward continuous 
learning and professionalism (Costa \& Kallick, 2008). Beyond course experiences, we expect students in the EdD program to develop these habits of mind by consistently engaging within the scholarly community in different ways. Thus we have included explicit activities that develop such habits via course and non-course experiences in the EdD program for the next cohort, and these should be considered by others who wish to develop cognitive presence beyond course topics in a program.

\section{Significance for Research in Online Programs}

The content analysis of online discussions and survey instruments have been the main methods used to assess teaching, social, and cognitive presence in online courses. In order to consistently assess teaching, social, and cognitive presence at a program level, the existing instruments should be expanded to consider the areas discussed in this paper. Existing indicators of cognitive, teaching, or social presence have to be adapted to analyze both asynchronous and synchronous interactions and course-specific and non-course-specific interactions in different learning spaces. There are challenges and choices associated with deciding which asynchronous or synchronous interactions should be analyzed across courses or virtual spaces in a program, for instance, with choosing random interactions in various program courses and from the virtual spaces where students communicate outside of courses in a program. The increase in the use of social media in online programs for professional networking and in professional organization activities, along with students' informal use of such virtual spaces to supplement their formal learning experiences, poses further complications in measuring how a community of inquiry develops within a cohort or students in an online program.

The CoI instrument developed by Arbaugh et al. (2008) is useful for studying the CoI framework in online courses, and we are reviewing it for use with the next cohort in the EdD program in educational technology. While it is possible to implement this instrument in multiple courses in a program, the results would not accurately reflect the interactions, mentoring, instructional design, administration, and support that contribute to the building of a community of inquiry at a program level. It is important to expand this instrument or else develop others for programs that encompass asynchronous as well as synchronous interactions, course-specific and non-course-specific activities in various virtual spaces, the involvement of multiple and diverse faculty members, and different types of learning objectives, including the application of knowledge and learning to practice.

\section{Conclusions}

Given the increase in the number of online programs in recent years (Allen \& Seaman, 2010), it is reasonable to assume there will be a subsequent increase in online degrees. Thus, there will be an associated need to develop protocols to investigate such programs. Based on the findings of this study, we suggest that the CoI framework of teaching, social, and cognitive presence is a useful lens through which to study online teaching and learning in professional practice programs. The CoI framework is commonly used to examine online courses, and our results suggest it can also be used in online programs, with an expand- 
ed role for each of the three primary areas of the framework. Teaching presence included program level design, implementation, organization, and responsibilities of faculty. Social presence included interactions outside of courses and the building of community using different types of interactions (synchronous and asynchronous) over a period of time. Cognitive presence included the development of habits of mind through course and non-course experiences. Further, in the context of online doctoral study, social and cognitive presences are also developed through interactions in professional organizations and with professionals outside of a doctoral program. Others wishing to develop similar programs will want to explicitly consider these areas as well as the use of the CoI framework in the design, implementation, and evaluation of their programs. 


\section{References}

Ainsworth, S., \& Loizou, A. T. (2003). The effects of self-explaining when learning with texts or diagrams. Cognitive Science, 27, 669-681.

Allen, I., \& Seaman, J. (2010). Learning on demand: Online education in the United States. Babson Park, MA: Babson College Survey Research Group. Retrieved from http:// www.sloanconsortium.org/publications/survey/pdf/learningondemand.pdf

Anderson, T., Rourke, L., Garrison, D. R., \& Archer, W. (2001). Assessing teaching presence in a computer conferencing context. Journal of Asynchronous Learning Networks, 5(2). Retrieved from http://www.aln.org/publications/jaln/v5n2/v5n2 anderson.asp

Arbaugh, J. B. (2005). How much does "subject matter" matter? A study of disciplinary effects in on-line MBA courses. Academy of Management Learning \& Education, $4,57-73$.

Arbaugh, J. B., \& Benbunan-Fich, R. (2006). An investigation of epistemological and social dimensions of teaching in online learning environments. Academy of Management Learning \& Education, 5, 435-447.

Arbaugh, J. B., \& Hwang, A. (2006). Does "teaching presence" exist in online MBA courses? The Internet and Higher Education, 9(1), 9-21.

Arbaugh, J. B., Cleveland-Innes, M., Diaz, S. R., Garrison, D. R., Ice, P., Richardson, J. C. \& Swan, K. P. (2008). Developing a community of inquiry instrument: Testing a measure of the Community of Inquiry framework using a multi-institutional sample. The Internet and Higher Education, 11(3/4), 133-136.

Arnold, N., \& Ducate, L. (2006). Future foreign language teachers' social and cognitive collaboration in an online environment. Language Learning \& Technology, 10(1), 42-66. Retrieved from http://llt.msu.edu/vol1onum1/pdf/arnoldducate.pdf

Benbunan-Fich, R., Hiltz, S. R., \& Harasim, L. (2005). The online interaction learning model: An integrated theoretical framework for learning networks. In S. R. Hiltz \& R. Goldman (Eds.), Learning together online: Research on asynchronous learning networks (pp. 19-37). Mahwah, NJ: Erlbaum.

Blignaut, A. S., \& Trollip, S. R. (2003). Measuring faculty participation in asynchronous discussion forums. Journal of Education for Business, 78(6), 347-353.

Celani, M. A. A., \& Collins, H. (2005). Critical thinking in reflective sessions and in online interactions. AILA Review, 18, 41-57.

Celentin, P. (2007). Online training: Analysis of interaction and knowledge-building patterns among foreign language teachers. Journal of Distance Education, 21(3), 
$39-58$.

Cepeda, N. J., Pashler, H., Vul, E., Wixted, J. T., \& Rohrer, D. (2006). Distributed practice in verbal recall tasks: A review and quantitative synthesis. Psychological Bulletin, 132(3), 354-380.

Costa, A. L., \& Kallick, B. (2008). Learning and leading with habits of mind: 16 essential characteristics for success. Alexandria, VA: ASCD.

Garrison, D. R., Anderson, T., \& Archer, W. (2000). Critical inquiry in a text-based environment: Computer conferencing in higher education. The Internet and Higher Education, 2(2/3), 87-105.

Garrison, D. R., Anderson, T., \& Archer, W. (2001). Critical thinking and computer conferencing: A model and tool to assess cognitive presence. American Journal of Distance Education, 15(1), 7-23.

Garrison, D. R. (2003). Cognitive presence for effective asynchronous online learning: The role of reflective inquiry, self-direction and metacognition. In J. Bourne \& J. C. Moore (Eds.), Elements of quality online education: Practice and direction, the Sloan C Series (Vol. 4, pp. 29-38). Needham, MA: The Sloan Consortium.

Garrison, D. R., \& Cleveland-Innes, M. (2005). Facilitating cognitive presence in online learning: Interaction is not enough. American Journal of Distance Education, 19(3), 133-148.

Gunawardena, C., \& Zittle, F. (1997). Social presence as a predictor of satisfaction within a computer mediated conferencing environment. American Journal of Distance Education, 11(3), 8-26.

Hughes, M., Ventura, S., \& Dando, M. (2007). Assessing social presence in online discussion groups: A replication study. Innovations in Education and Teaching International, 44(1), 17-29.

Iriberri, A., \& Leroy, G. (2009). A life cycle perspective on online community success. ACM Computing Surveys, 41(2). Retrieved from http://web.cgu.edu/faculty/leroy/content/Publications.html

Kanuka, H., Rourke, L., \& Laflamme, E. (2007). The influence of instructional methods on the quality of online discussion. British Journal of Educational Technology, 38(2), $260-271$.

Lim, C. P., \& Barnes, S. (2002). "Those who can, teach"-The pivotal role of the teacher in the information and communication technologies (ICT) learning environment. Journal of Educational Media, 27(1-2), 19-40. 
Luebeck, J. L., \& Bice, L. R. (2005). Online discussion as a mechanism of conceptual change among mathematics and science teachers. Journal of Distance Education, 20(2), 21-39.

McTighe, J., \& O’Connor, K. (2005). Seven practices for effective learning. Educational Leadership, 63, 10-17.

Meyer, K. A. (2003). Face-to-face versus threaded discussions: The role of time and higherorder thinking. Journal of Asynchronous Learning Networks, 7(3), 55-65.

Meyer, K. A. (2004). Evaluating online discussions: Four different frames of analysis. Journal of Asynchronous Learning Networks, 8(2), 101-114.

Molinari, D. L. (2004). The role of social comments in problem-solving groups in an online class. American Journal of Distance Education, 18(2), 89-101.

Moore, M. G., \& Anderson, W. G. (Eds.). (2003). Handbook of distance education. Mahwah, NJ: Lawrence Erlbaum Associates.

Moreno, R., \& Valdez, A. (2005). Cognitive load and learning effects of having students organize pictures and words in multimedia environments: The role of student interactivity and feedback. Educational Technology Research and Development, 53(3), $35-45$.

Murphy, E. (2004). Recognizing and promoting collaboration in an online asynchronous discussion. British Journal of Educational Technology, 35(4), 421-431.

Perry, J. A., \& Imig, D. G. (2008). A stewardship of practice in education. Change: The Magazine of High Learning, 4O(6), 42-49.

Richardson, J. C., \& Swan, K. (2003). Examining social presence in online courses in relation to students' perceived learning and satisfaction. Journal of Asynchronous Learning Networks, 7(1), 68-88.

Rourke, L., Anderson, T., Garrison, D. R., \& Archer, W. (2001). Assessing social presence in asynchronous text-based computer conferencing. Journal of Distance Education, 14. Retrieved from http://auspace.athabascau.ca:8080/dspace/handle/2149/732

Rovai, A. P. (2002). Sense of community, perceived cognitive learning, and persistence in asynchronous learning networks. The Internet and Higher Education, 5(4), 319-332.

Shea, P. J., Fredericksen, E. E., Pickett, A. M., \& Pelz, W. E. (2003). A preliminary investigation of teaching presence in the SUNY learning network. In J. Bourne \& J. C. Moore (Eds.), Elements of quality online education: Practice and direction, the Sloan $C$ Series (Vol. 4, pp. 279-312.) Needham, MA: Sloan Center for Online Education. 
Shea, P. J., Pickett, A. M., \& Pelz, W. E. (2004). Enhancing student satisfaction through faculty development: The importance of teaching presence. In J. Bourne \& J. C. Moore (Eds.), Elements of quality online education: Into the mainstream, the Sloan CSeries (Vol. 5, pp. 39-59). Needham, MA: Sloan Center for Online Education.

Shea, P., Hayes, S., \& Vickers, J. (2010). Online instructional effort measured through the lens of teaching presence in the community of inquiry framework: A re-examination of measures and approach. The International Review of Research in Open and Distance Learning, 11(3). Retrieved from http://www.irrodl.org/index.php/ irrodl/article/view/915

Shulman, L., Golde, C. M., Bueschel, A. C., \& Garabedian, K. J. (2006). Reclaiming education's doctorates: A critique and a proposal. Educational Researcher, 35(3), 25-32.

So, H. J., \& Brush, T. A. (2008). Student perceptions of collaborative learning, social presence, and satisfaction in a blended learning environment: Relationships and critical factors. Computers \& Education, 51(1), 318-336.

Swan, K. (2003). Developing social presence in online discussions. In S. Naidu (Ed.), Learning and teaching with technology: Principles and practices (pp. 147-164). London: Kogan Page.

Swan, K. (2004). Learning effectiveness: What the research tells us. In J. Bourne \& J. C. Moore (Eds.), Elements of quality online education: Practice and direction, the Sloan C Series (Vol. 4, pp. 13-45). Needham, MA: Sloan Center for Online Education.

Swan, K., \& Shih, L. F. (2005). On the nature and development of social presence in online course discussions. Journal of Asynchronous Learning Networks, 9(3), 115-136.

Wu, D., \& Hiltz, S. R. (2004). Predicting learning from asynchronous online discussions. Journal of Asynchronous Learning Networks, 8(2), 139-152.

\section{Athabasca University $\mathbf{I}$}

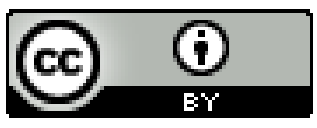

